\title{
Comparative Analysis of Risk Management in Conventional and Islamic Banks: The Case of Bosnia and Herzegovina
}

\author{
Emira Kozarević ${ }^{1}$, Senija Nuhanović ${ }^{1} \&$ Mirnesa Baraković Nurikić ${ }^{1}$ \\ ${ }^{1}$ Faculty of Economics, Tuzla University, Tuzla, Bosnia and Herzegovina \\ Correspondence: Emira Kozarević, Faculty of Economics, Tuzla University, Univerzitetska 8, 75000 Tuzla, \\ Bosnia and Herzegovina. Tel: 387-35-320-840 \& 387-61-178-821. E-mail: emira.kozarevic@untz.ba
}

Received: March 4, 2013

Accepted: March 27, 2013

Online Published: April 17, 2013

doi:10.5539/ibr.v6n5p180

URL: http://dx.doi.org/10.5539/ibr.v6n5p180

\begin{abstract}
Any banking activity involves a certain level of risk. Regardless of the fact that risk has always been present in banks, active risk management in conventional banking started only in the 1990s, specially after the collapse of Barings PLC, the bank with more than 200-year-old tradition, while such practice is still underdeveloped in Islamic (interest-free) banking whose practical implementation in the world started only in the 1970s. However, in the times of the recent sub-prime mortgage crisis and a large number of collapses and near collapses, multibillion losses and write-offs all banks, whether conventional or Islamic, saw the necessity for active risk management. Specific features of banks in Bosnia and Herzegovina and their way of managing risks are conditioned by a particular legal framework. This framework regulates primarily the conventional banks, but it indirectly affects the Islamic bank as well, since it does not allow the bank to offer all types of products and services which are generally present in Islamic banking. Since, to our knowledge, not a single specific comparative research into conventional and Islamic banks has been done in this part of the world, the aim of this paper is to provide an insight into risk management practiced by $\mathrm{BiH}$ banks, and to determine the dependence of their financial performance on the process of active risk management.
\end{abstract}

Keywords: risk management, conventional banks, Islamic bank(s), Bosnia and Herzegovina (BiH)

\section{Introduction}

The meaning of the word "risk" (Arab "mukhatarah") has changed over the years. Understanding the true meaning of risk and its basic components took a lot of time and efforts. Risk is defined as the situation which includes the probability of diverging from the paths that lead to the expected or common result (E. Vaughan \& T. Vaughan, 1999). In simple terms, it is a probability that the events shall happen, which are opposite of expected, in the respect that such divergence can be positive (upside) and negative (downside). The upside risk is desirable but rarely possible in everyday life. Conversely, the risk component from which both individuals and organization want to protect and, if possible, manage it actively is the downside risk.

In its business activities, a bank and its managers constantly and inevitably face a growing number of risks, out of which the most common are: credit, liquidity, market, and operational risks. However, there are some differences in terms of kinds and span of certain risk types when it comes to the conventional and Islamic banking. Nowadays, there is a large number of new types of risk that all financial institutions face. The basic feature of all their risks is the constant increase in the intensity of the emergence of the existing risks as well as the appearance of new, so far unknown, types of risks. There are several basic factors leading to these processes such as: increased volatility of financial markets, globalization and increased competition in financial markets, financial innovations and "drop" of traditional banking business practice, and regulatory environment of financial institutions, especially banks (Iqbal \& Mirakhor, 2009).

Risk management is a part of business policy of every bank. In order to appropriately implement the active risk management process, it is necessary to observe the process through some of its successive stages that differ when it comes to the conventional and Islamic banking. However, a comprehensive process of risk management in all financial institutions should include the following components: establishment of appropriate environment for risk management, finding appropriate "mitigators" of risk, risk measures, and appropriate internal controls (Khan \& Ahmed, 2001). 
Globalization of business activities conducted by financial institutions, as well as negative consequences of the former financial crises round the world contributed to the growing need for the development of methods and/or models for risk management, which are on the increase lately.

As far as $\mathrm{BiH}$ banks are concerned, the field of their risk management practices is almost completely unexplored. On the one hand, the fact is that the financial system in $\mathrm{BiH}$ is not developed in terms of the variety of not only financial institutions but also of financial instruments. On the other hand, it is also known that most of BiH banks are basically subsidiaries of large EU banks and, consequently, some of them started to implement the Basel II standards before the official date posed by the Central bank of BiH (the end of 2008) in order to meet their parent banks' requirements. In addition, one of BiH banks operates on the principles of Islamic banking and it is the only Islamic bank in Southeastern Europe. However, similarities and differences between the BiH Islamic bank's risk management practice and risk management practices of other BiH banks (i.e. conventional) are still unknown. Accordingly, the aim of this study is to investigate the practice of risk management techniques in $\mathrm{BiH}$ banking sector and to make the comparison between several conventional banks and one Islamic bank.

\section{Literature Review}

Considering the relevant literature, it seems that the comparative analysis of risk management in conventional and Islamic banks has been the subject of research of a certain number of scientists worldwide only since the beginning of the $21^{\text {st }}$ century, especially since the outbreak of the global financial crisis.

Tafri, Rahman, and Omar (2011) conducted a survey whose main objective was to examine the current practices and future trends in risk management methodologies of Islamic and commercial banks in Malaysia and selected Islamic banks outside Malaysia. In particular, the authors wanted to identify the methods and tools used in managing market, credit, and operational risk among Islamic and conventional banks, as well as to answer the question of whether there is a convergence in the practice of risk management and risk mitigation between Islamic and conventional banking systems, especially with regard to the major risks. The findings in the study suggested that there are significant differences between Islamic and conventional banks in the extent of usage of: market Value-at-Risk (VaR), stress testing results, credit risk mitigation methods, and operational risk management tools. As the majority of Islamic banks are still in the early phase of operational risk management implementation, these tools are not extensively used by the Islamic banks, relative to conventional banks. In the case of stress testing, it was concluded that currently there is no uniform approach regarding the types of stress testing undertaken, its frequency, or actions taken in response to the results; by implication, more work should be done in defining standards for stress testing. Therefore, it could have been concluded that there is no convergence in the use of risk management tools between Islamic and conventional banks; this could possibly be due to the different nature of the banks and also the lack of tools which are non-riba based (interest-free) and Shari'ah (Islamic law) compliant. The evidence also suggests that risk management tools and systems for Islamic banking are seen as inadequate, particularly in the critical areas of: "IT professionals with relevant expertise in the process integration and risk analytics", "IT systems to cater for each Islamic instrument", and the "capacity of human capital in the highly technical areas of risk measurement". This implied that more innovations and product developments are needed for Islamic banking in managing risks.

A comparison of conventional and Islamic banks in Pakistan in terms of risk management was made by Nazir, Daniel, and Nawaz (2012). Using a questionnaire survey method, they found that Pakistani banks are efficient in credit risk analysis, risk monitoring, and understanding the risk in the most significant variables of risk management. Moreover, there is a significant difference in risk management practices of the Islamic and conventional banks of Pakistan. It was suggested in the study that Islamic and conventional banks should be different in credit risk analysis. But due to little innovation in credit risk assessment in Islamic banks, most Islamic banks have adopted the same procedure that is adopted by the conventional banks.

As far as credit risk is concerned, Boumediene (2011) explored the assertion that Islamic banks have higher levels of credit risk (the risk of counterparty failure) than their counterparts in conventional finance, based on the fact that Islamic banks do not have the appropriate risk management tools to deal with such risk. The author gave definitions, methods for identification, and methods for management of credit risk for the following Islamic financial tools: musharakah (joint venture), mudarabah (sell at a profit, profit-sharing), istisna' (object deferred sale), salam (pre-paid sale), ijarah (lease), and murabahah (cost-plus or mark-up sale). The risk was then calculated for nine Islamic banks and nine conventional banks using the contingent claims analysis (CCA). Merton's model, based on Black and Scholes's option pricing formula, was used to measure the distance-to-default (DD) and the default probability (DP) from 2005 to 2009. The Islamic banks had a mean distance-to-default of 204, significantly higher than conventional banks ( $\mathrm{DD}=15)$. The mean default probabilities 
were 0.03 and 0.05 , respectively. Cumulative logistic probability distributions were then used to derive default probability from distance-to-default. These results were more satisfying: the distribution of default probability had larger tails, responding to the criticism of the use of a normal distribution. In other words, it was empirically demonstrated that Islamic banks have a lower credit risk than conventional banks.

Furthermore, Abdullah, Shahimi, and Ismail (2011) assessed key issues in measurement and management of operational risk in Malaysian Islamic banks. They suggested that several issues around risk still need to be clarified and addressed further. The fact that there is a variety and unique nature of financing and investment activities of Islamic banks, each one having its' own risk characteristics, affects both sides of the bank's balance sheet. While basic Basel core principles of effective banking supervision apply equally well and ideally suit Islamic banking institutions, risk measurement and risk management practices still need specific adaptations to Islamic banks' operational characteristics. These particularities highlighted the unique characteristics of Islamic banks and raised serious concerns regarding the applicability of the Basel II methodology to Islamic banks. This will set the stage for adopting more advanced capital measurement approaches as envisaged in Basel II, but tailored to the specific operational characteristics of Islamic banks.

Besides that, Anam, Hasan, Huda, Uddin, and Hossain (2012) conducted a comparative study between conventional and Islamic banks of Bangladesh in perspective of liquidity risk management (LRM). The researchers assessed the extent of liquidity risk associated with these institutions and evaluated the concurrent LRM. They tried to investigate the significance of bank's size, net working capital, return on equity, capital adequacy, and return on assets on LRM. Secondary data had been the major stimulus of the research covering five year period 2006-2010. A model estimation to predict the liquidity risk level was proven to be successful for Islamic banks, but the module failed to generate the desired result in case of conventional banks. Moreover, net working capital in case of conventional banks and size of the business in case of Islamic banks was found to be positive and significant at $5 \%$ significance level.

Hussein (2010) investigated the behavior of four key bank-level stability factors, as follows: liquidity, capital, risk-taking, and consumer confidence, in both Islamic and conventional banks that operate in the same market. Using a fixed effect for a sample of 194 banks of Gulf Cooperation Countries (GCC) between 2000 and 2007, the author found that liquidity is not determined by the bank's product mix but rather attributed to systematic factors. However, nonperforming assets (representing loans to sub-prime borrowers) have a positive and significant relationship with liquidity, implying that during the crisis Islamic banks tend to take stringent risk strategies compared to conventional banks. Furthermore, Islamic banks generally tend to provide higher consumer confidence levels as they were more capitalized than conventional banks, although conventional banks carried higher averages of liquidity compared to Islamic banks. Consumer confidence levels or depositors' discipline as assessed by deposits and customer funding over total liabilities generally appear to be higher in Islamic banks than conventional banks in GCC.

The above literature of all the past studies figured out the risk management practices adopted by different types of banks from all over the world. There are different types of risk faced by different types of banks. This study is conducted to explore the risk management practices in $\mathrm{BiH}$ adopted by the conventional and Islamic banks and try to figure out the difference of adoption of several aspects such as risk identification, risk analysis and evaluation, core approach to managing risks (active/passive), hedging instruments, etc.

\section{Theoretical Background}

The raison d'être of risk management consists of the following elements: first, identification and evaluation of risk is made, and then the users of appropriate banking products and/or service are charged with the risk price, whereby one portion of the collected price is set aside into the reserves and shareholding capital of a bank. After that it is necessary to break even the expected losses from the reserves and the unexpected losses from the bank's capital and form the risk-adjusted capital (economic capital) and perform risk monitoring by a special department at the bank.

However, there are certain differences when analyzing the expected loss for conventional and Islamic banks. Actually, such differences appear in the way of breaking even the loss, caused by different types of products and services which these banks offer to their clients. In a conventional bank (see Figure 1), the expected loss is broken even from the profit made by a bank in that period; the unexpected loss is to a certain extent broken even from the bank capital while the amount above that level is refunded from the insurance or the bank accepts bankruptcy. 


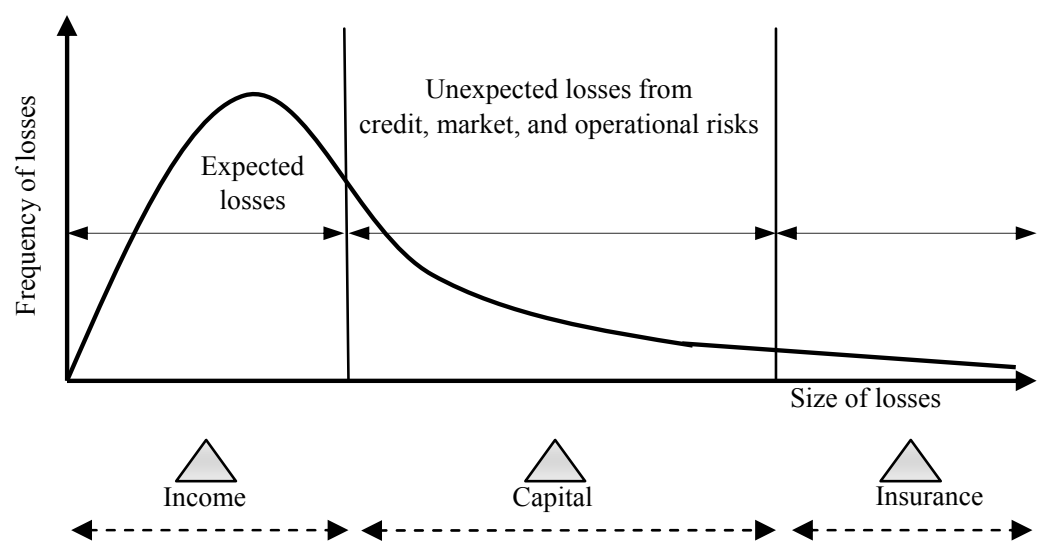

Source: Khan, 2004.

Figure 1. Sustaining losses in conventional banks

Islamic banks break even the expected loss from the provision income, the unexpected loss, to a certain of reliability, is refunded from the Profit Sharing Investment Accounts (provided that the unexpected loss was a result of investment into Profit Sharing Investment Accounts) or from the bank capital (provided that the unexpected loss was a result of other bank activities), while above that level the insurance, that is takaful, is accepted (Figure 2).

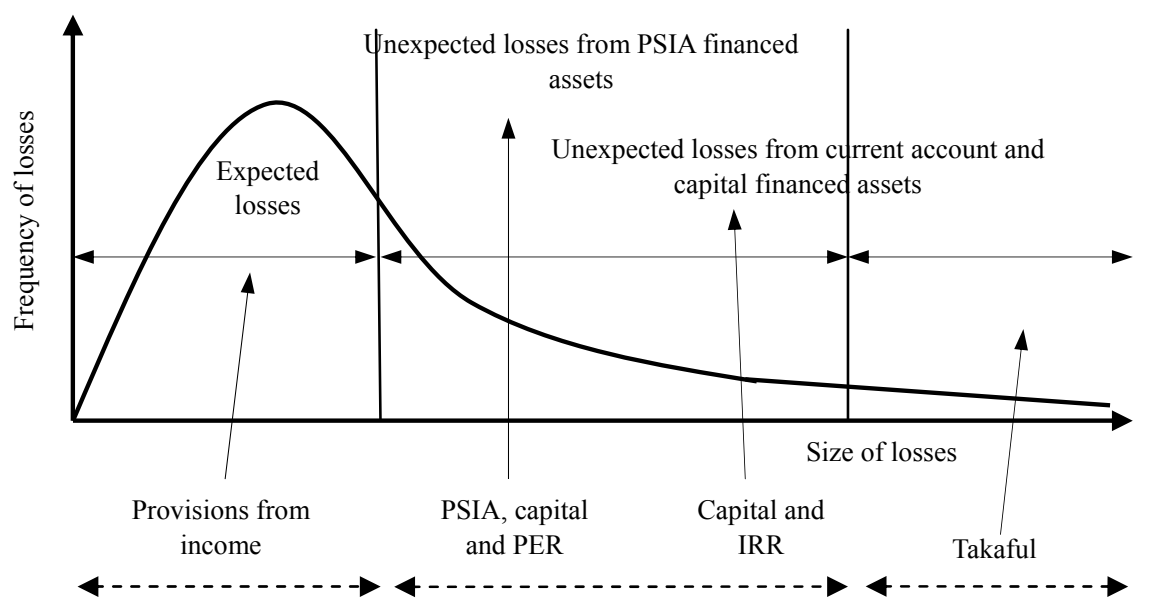

Figure 2. Sustaining losses in Islamic banks

Notes: PSIA - Profit Sharing Investment Accounts; PER - Profit Equalization Reserve; IRR - Investment Risk Reserve.

Source: Khan, 2004.

Furthermore, due to their constant change and mutual interactions, it would be impossible to cover all types of risk that banks, whether conventional or Islamic, face. We believe that risks in conventional banks, due to analytical reasons, can be divided into some of the following types of risk:

- market risk,

- credit risk,

- liquidity risk,

- operational risk, and

- other types of banking risks.

Market risk appears in trading or investing into the instruments of assets and liabilities due to the change in interest rates, exchange rates or securities' prices (Šverko, 2002). Credit risk is the risk of potential debtors/loan applicants or other related persons that did not fulfill their contract obligations to the bank. Liquidity risk is the risk to which present and future earnings are exposed, as well as the bank capital. It appears due to the failure of 
bank to fulfill its obligations when they mature without the appearance of unacceptable risks or costs. Operational risk is related to the possibility of negative effects on the financial result and bank capital, which are the consequences of employees' negligence, inappropriate internal procedures and processes, inappropriate management of information and other systems, or they appear as a result of unpredictable external events. Other types of risk in conventional banks include: bank exposure risk (to clients or other banks), investment risk, legal risk, strategic risk, and country risk.

Besides most of the risks faced by conventional banks (such as one part of credit, market, operational, and liquidity risk), Islamic banks have special types of risk that are specific to their business operations in compliance with Shari'ah. In Islamic banking, all types of risk can be divided as follows:

- financial risk,

- business risk,

- treasury risk,

- management risk, and

- other types of risk in Islamic banks.

One of the basic types of risk faced by Islamic banks is the financial risk. Its result is a direct financial loss on the bank assets and liabilities. Business risks appear due to various macroeconomic and political conditions, but also due to insolvency which is a result of the lack of resources for the continuation of business activities. The treasury risk includes the risks that appear in the management of Islamic bank financial resources: cash management, ownership management, short-term liquidity management, as well as bank assets and liabilities management. "Management risk is related to the risk that appears due to unsuccessful bank management, negligence in running business and fulfilling contract obligations, as well as due to weak internal and external institutional environment, including the legal risk as well, when banks cannot implement their contracts" (Iqbal \& Mirakhor, 2009). Apart from these types of risk, Islamic banks have other types of risk specific to certain products offered by these banks. Such risks appear only when certain business activities are not performed in a way which is expected in Islamic banks.

Islamic banks have some risks that are identical to the risks faced by conventional banks. However, these banks are exposed to some specific risks. The ratio of certain types of shared vs. unique risks for both types of banks is illustrated on Figure 3.

\section{Islamic banks' types of risk}

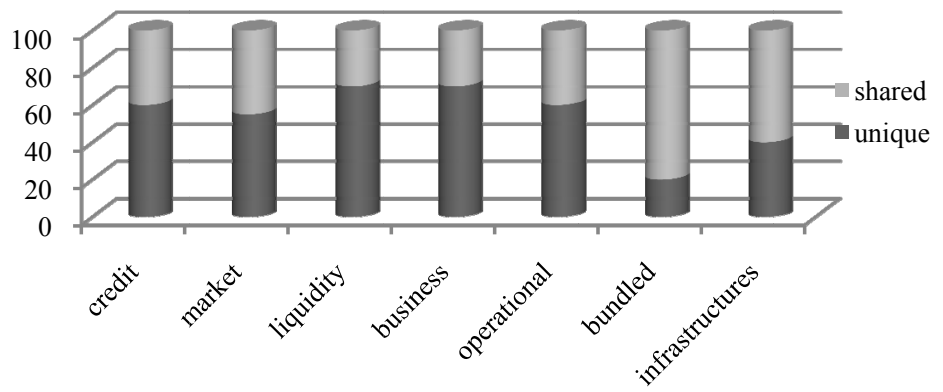

Figure 3. Shared and unique risks in conventional and Islamic banks

Source: Khan \& Ahmed, 2001.

Despite different views regarding the number and span of the stages of active risk management in conventional banks, four basic stages of this process can be isolated (Kozarević, 2009):

- risk identification,

- risk evaluation,

- selection of method for risk management, and

- implementation and result assessment.

Risk identification is the first step in the entire process of active risk management. It includes the comprehension 
of potential losses based on the total exposure to various types of risk. Risk evaluation assesses potential losses in such a way that it determines the probability of their appearance in a certain period of time, assesses their possible size, and finally ranks potential losses by means of importance. The selection of method for risk management is made on the basis of the probability and size of the identified potential losses. One can select one of the risk management methods, but also several of them in combination. After determining the method by which one wants to manage risks, what follows is the creation and implementation of measures. The control of the implemented risk management methods, as well as the assessment of the results obtained, must be performed periodically due to changeable conditions and circumstances in which banks operate, which were considered during the result assessment.

In terms of Islamic banks, the system for risk management in these banks includes several successive stages as follows:

- risk identification,

- risk and capital quantification,

- gathering or grouping similar risks,

- previous controls, and

- risk monitoring.

As conventional banks, Islamic banks have risk identification as the initial stage of the process of risk management. This stage should provide the size of a possible loss of the bank on the basis of exposure to all types of risk. However, Islamic bank have a task that is much more difficult than for conventional banks, since they are exposed to specific types of risk as well, that are generated by their special ways of financing. After the identification of all types of risk, they need to be quantified. This means that for each type of risk one should determine the highest possible loss caused by it, and use it as the basis for making the necessary reserves from the basic capital of the bank. This is an extremely significant stage in Islamic banks due to the fact that they are exposed to a wide spectrum of risks. This is why the risks frequently need to be divided into certain groups with the same or similar characteristics. Previous controls are necessary so as to check whether the conditions have been made for the execution of each stage of risk management, failure of which requires certain measures to be taken so that all involved in a certain stage of this process have the appropriate work conditions. Since the process of risk management is continuous and it is per se constantly repeated, permanent monitoring needs to be made so as to ensure that all the stages of the process run without halts or difficulties.

Specially, since the mid 1980s numerous models and ways for risk management have been developed. They are mainly based on the concept of loss probability distribution, meaning the change in the bank portfolio value. There are different ways for risk management in conventional banking, among which the most used one is the so called value at risk concept (more known under the acronym VaR). Other risk management methods also include: expected loss concept (EL), conditional value at risk concept (CVaR), stress-testing, and backtesting. $\mathrm{VaR}$ is actually a statistical measure of bank's probable losses that emerge as a result of usual market changes. That is the maximum loss that can appear at a given level of tolerance in a specific time interval. The EL concept is based on determining the expected loss provided that some unpredicted circumstances appear. If VaR is exceeded, some banks can have different expected losses with the same VaR, which then lead to a new risk measure, the so called CVaR. The simplest explanation of the conditional value at risk is that it represents the expected final loss if $\mathrm{VaR}$ is crossed, and it is a better risk measure that VaR, but also more complicated as it requires the assessment of the total distribution of bank losses, etc.

Although risk identification is rather developed in Islamic banks, techniques and models for risk assessment and management are still insufficiently developed or only beginning to develop. One of the quantitative methods of risk measurement suggested by Islamic banking experts is similar to the VaR model in conventional banks. According to this method, the risk of investors in Islamic banks can be quantified by the assessment of profit exposed to risk (Profit at Risk - PaR), which is based on the historical profit and return volatility.

As all banks face a large spectrum or risks, whose intensity has been constantly increased, banks started introducing certain banking products in their business activities. These products help them in protection against risk, as well as in the decrease of negative consequences caused by a certain risk in bank business operations. Each of these risk protection products can lower a specific type of risk to a certain level, while almost none of them can fully eliminate all types of risk. Some of the banking products mostly used in banks for protection against risk are as follow (Rose \& Hudgins, 2005):

- bank loans securitization, 
- selling loans off-balance,

- standby letters of credit, and

- credit derivatives such as

- credit exchange,

- credit options,

- exchange of credit defaults,

- credit related bills of exchange and

- collateralized debt obligations.

However, the abovementioned financial instruments are not entirely allowed in Islamic banking. Actually, only certain modalities of these products are allowed, as they do not comply with the principles of Shari'ah which are obligatory for banking business operations.

\section{Methodology}

The financial system of $\mathrm{BiH}$ is, in the proper sense of the word, bank-centric. For many years over $80 \%$ of the assets of all the financial institutions in BiH belong to the banks. The organized financial market has functioned only since mid 2001 in the form of Sarajevo (SASE) and Banjaluka Stock Exchanges (BLSE). However, daily turnovers of these stock exchanges are on average BAM 200 thousand, and the trade is mainly in common stocks, with a low share of municipal bonds, bonds of the Ministry of Finance, corporate bonds, etc. Besides that, the banks in $\mathrm{BiH}$, totaling to 28 out of which one bank is under temporary administration (Postbank $\mathrm{BH}$ ) and two are the entity development banks (the Federation of BiH Development Bank and the Republic of Srpska Investment-Development Bank) are primarily conventional banks. Practically, they are non-transparent financial institutions which they mainly use as an "excuse" for their indifference to academic research.

Although risk management has been present in most banks ever since they were established, there are still many problems the banks in $\mathrm{BiH}$ meet, which make their risk management more difficult. This is especially true for the Islamic bank, Bosna Bank International (BBI) for which the legal regulations have still not been made, which would allow for all the aspects of the Islamic banking. BBI was established in 2000 by the Islamic Development Bank, Dubai Islamic Bank, and Abu Dhabi Islamic Bank, with the aim of introducing Islamic banking on the territory of Southeastern Europe. This is the only Islamic bank which operates in $\mathrm{BiH}$, but in fact it is only a "hybrid" Islamic bank as the existing laws on banks in BiH entities - Bosnia and Herzegovina Federation (F $\mathrm{BiH}$ ) and Republic of Srpska (RS) - allow for Islamic banking to be applied only in a very small capacity. However, the Law on Banks in F BiH is currently subject to amendments, and one of the provisions insisted upon by the Banks Association of $\mathrm{BiH}$ is that the banks are allowed to "use in their business activities the products based on partnership and buying and selling with a margin, but only for the purpose of crediting-financing bank clients". Provided that this amendment is accepted, the regulations are to be changed for the benefit of Islamic banking.

This particular research, which was created to provide an insight into risk management practiced by BiH banks (conventional and Islamic) and determine the dependence of their financial performances on the process of active risk management, was conducted by the survey method and using a questionnaire technique. The questionnaire included a total of 25 questions and it was delivered to $\mathrm{BiH}$ banks via their e-mail addresses. The survey questionnaire was self-developed and it contained several types of closed-ended questions employed, including single response, multiple response, ranking response, and five-point scale questions.

The survey was conducted from the end of March to the beginning of July 2012. The banks (apart from BBI and Raiffeisen Bank $\mathrm{BiH}$ ) were passive at first, but the problem was overcome through direct communication with the management staff, making precise details, and pointing to the persons competent for the survey. At the end, a total of nine banks filled in the questionnaires (eight conventional banks and $\mathrm{BBI}$ ), which results in response rate of $36 \%(9 / 25)$.

The results obtained in this research take into consideration the fact that there are certain limitations such as institutionally limited application of Islamic banking and the comparison between risk management ways of the only Islamic bank in $\mathrm{BiH}$ and the average of eight other conventional banks surveyed.

\section{Results and Discussion}

The research revealed that all the banks surveyed have their organization units in charge of risk management, that is, risk identification, risk measurement, selection of methods for risk control, etc. The number of employees 
in risk departments varies significantly. Thus, some banks have only two employees, while some have as many as 100 employees in charge of risk management activities.

All the banks identify risks on the basis of the analysis of financial statements, analysis of past experiences, and exchange of information both between certain organization units and with external partners. One of the important means of risk identification is analysis of contracts. A number of $62.5 \%$ of the respondents agreed with this, while $37.5 \%$ of the respondents do not use this method for risk identification. Twenty-five percent of the banks stated that they use interview, flow diagram, and hazard analysis to identify risk, while $75 \%$ of the respondents stated that they do not use any of these methods. Regarding other means for risk identification, the respondents mentioned cash flow projection, internal ranking of clients, credit analysis (analysis of financial statements), signs of early warning, risk assessment, etc. While most banks in the developed parts of the world use the combination of all the means of risk identification, banks in $\mathrm{BiH}$ to a small degree use some types of risk identification, which can certainly help in the early discovering of risk. This should be explained by insufficient knowledge of all the methods for risk identification, as well as by a specific resistance to the introduction of new ways of risk identification.

If the means for risk identification are to be compared between conventional and Islamic banks, the situation would look like the one presented on Figure 4. It is evident that the Islamic bank uses the following methods for risk identification: analysis of financial statements, flow diagram, analysis of contracts, analysis of past experiences, and exchange of information both between certain organization units and with external partners. The Islamic bank does not use other methods such as: questionnaires, interview, and hazard analysis. It is important to mention that those means for risk identification, which are not used by Islamic banks, are to a small percentage used by conventional banks (less than 30\%) and only recently. Also, flow diagram, regularly used by the Islamic bank, is used by only $14.29 \%$ of the conventional banks, while analysis of contracts is used by $57.14 \%$ of the conventional banks.

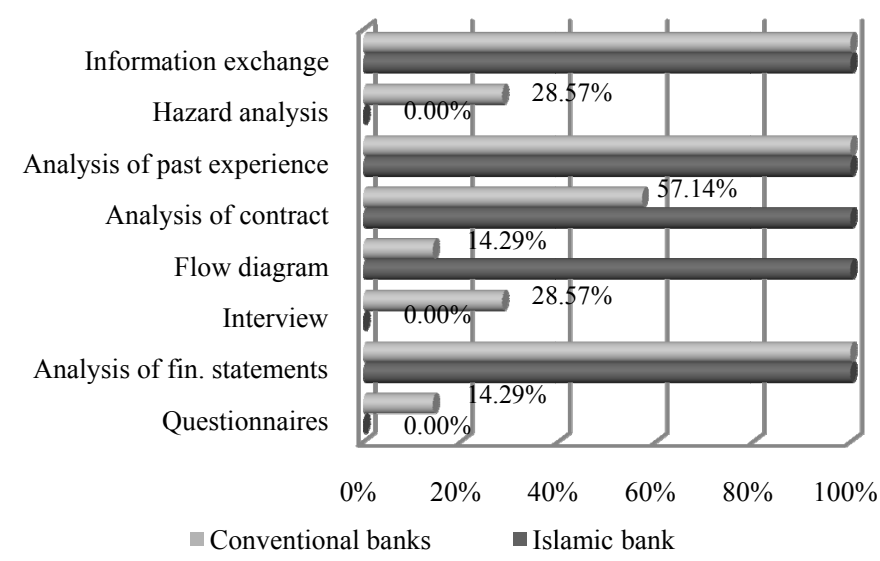

Figure 4. A comparison of risk identification methods in conventional and Islamic banks

After risk identification, the next stage in the entire process of risk management is to specify all the risks to which a bank is exposed in its business operations. All the respondents stated that they need to manage, in accordance to requirements (a.k.a. "decisions about minimal standards...") of the appropriate entity banking agency, credit risk, liquidity risk, operational risk, market risk, and foreign currency risk. Besides these basic types of risk, there are also the types of risk that $\mathrm{BiH}$ manage arbitrarily, as the source of making added value (avoiding losses and increasing profit): reputation risk, strategic risk, earnings risk, settlement risk, investment risk, risk of active and passive interest rates, etc. Both, conventional and the Islamic banks stated the same types of risk they have to manage. Thus, in this case there were no differences in answers of these two types of banks. The basic reason lies in the fact that regulation for conventional and Islamic banks is still the same.

However, there are certain differences in terms of the effect intensity of certain types of risk in conventional and Islamic banks. Figure 5 shows that intensity of the emergence of all types of risk is higher for the Islamic bank. The respondents at the Islamic bank confirmed "high" intensity of the emergence of the following types of risk: credit risk, liquidity risk, and operational risk, while they stated that the market risk has a "medium" intensity of the emergence. In comparison to the Islamic bank, the conventional banks have a smaller intensity of the emergence of all risks. The respondents rated all the risks with "medium" intensity of the emergence. Out of 
other risks present in banks, the conventional banks also singled the foreign currency risk, for which they stated that it has a "slow" intensity of the emergence, but with the influence on banks' business operations.

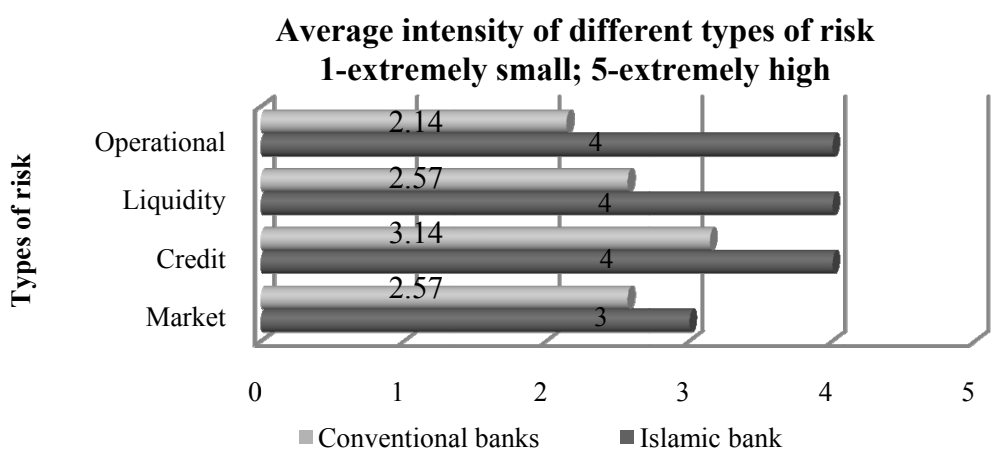

Figure 5. Intensity of the emergence of specific risk types in conventional and Islamic banks

Regarding the trends of certain types of risks in banks in the last three years, the respondents in the Islamic bank stated that all the risks were stable. This means that, although a higher intensity is present for all the types of risk, this bank keeps them at a specific level and prevents their increase. In the conventional banks the situation is somewhat different in relation to some types of risk. For instance, $57 \%$ of the respondents stated that the market risk is stable, while $43 \%$ stated that it is on the increase. Regarding the credit risk, the respondents stated it to be decreasing, stable, and increasing (14\%, 57\%, and 29, respectively), what is illustrated on Figure 6.

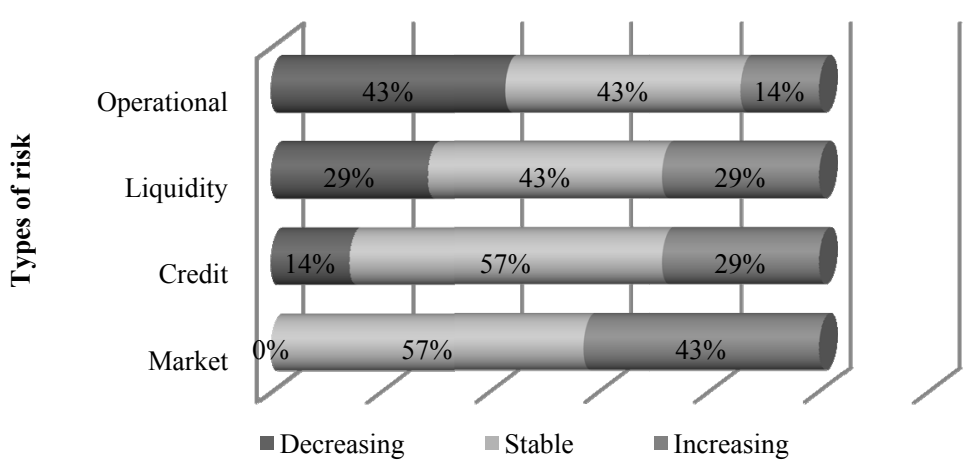

Figure 6. Specific risk types' trends in conventional banks

Regardless of its large influence on banks' business operations, the banks in $\mathrm{BiH}$ still do not have sufficiently developed ways in which they would manage risk. Although the specific methods have been mentioned above by which the banks in the developed world manage risks, BiH banks use only some of them, and not entirely. Those are for example: VaR, interest rate gap, sensitivity, internal ranking, gap of source and investment maturity, analysis of open foreign currency position, etc. All the banks surveyed stated that they perform active risk management, meaning that they have the entire process, starting from risk identification, over risk measurement, appropriate reserve creation, to the selection of specific methods for risk control, etc. This is very important, as it supports the statement that all banks, including those in $\mathrm{BiH}$ as well, have become aware of the importance of active risk management.

Seventy-five percent of the banks surveyed have practiced active risk management by risk types since they were established, while $25 \%$ of the banks started several years after foundation. According to the opinions of all the respondents, the process of active risk management of all risk types actually leads to the improvement of financial performance and enables the avoidance of significant business losses. All the respondents answered that most total risks $(59 \%)$ does not hinder business operations and that the banks were able to control these risks so far. A somewhat lower percentage of total risks (38\%) moderately hinders business operations, while only $3 \%$ of all the risks largely hinders business operations and the banks have serious problems when managing these risks (Figure 7). 


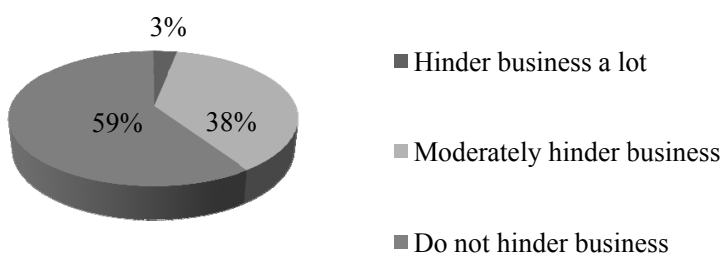

Figure 7. Overall risk impact on $\mathrm{BiH}$ banks’ business

However, the impact of some types of risk on business operations of conventional banks is not identical, which can be seen on Figure 8. The respondents in the Islamic bank stated that all types of risk do not hinder their business operations at all. The main reason lies in the fact that Islamic banks use different business principles and different types of products.

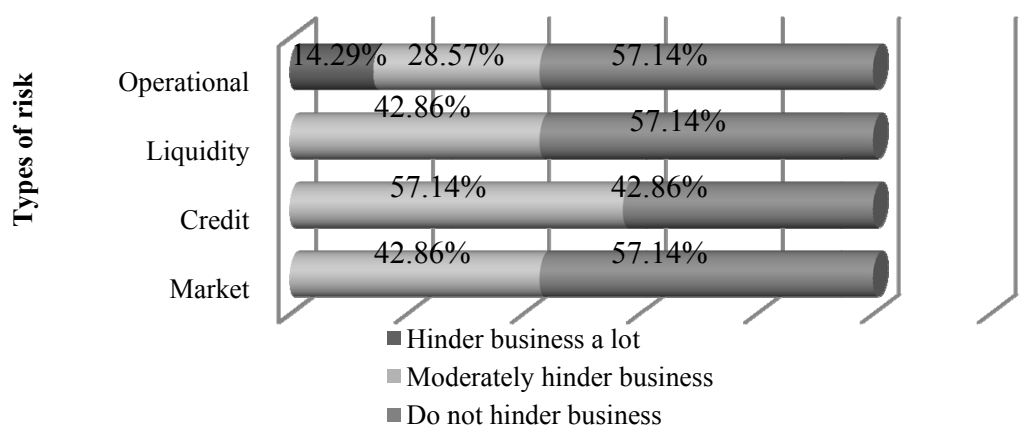

Figure 8. Specific risk types' impact on conventional banks’ business

Due to the existence of different types of risk in banks, they are forced to use certain hedging instruments. As the financial market is underdeveloped, the banks in $\mathrm{BiH}$ can use only a small number of such instruments (see Figure 9). The banks in $\mathrm{BiH}$ do not use futures, swaps, and options at all. On the contrary, all the banks use collateral as their basic hedging instrument as well as the appropriate reserves for potential losses. Guarantees are also significantly used as a hedging instrument (88\%). Out of other hedging instruments we can single out insurance, meaning the appropriate insurance policy and forwards. When conventional and Islamic banks are compared, it can be concluded that the usage of forwards, futures, swaps, and other term agreements is not allowed in the Islamic bank. That is why this bank has a smaller possibility to protect itself against risks by means of appropriate hedging instruments.

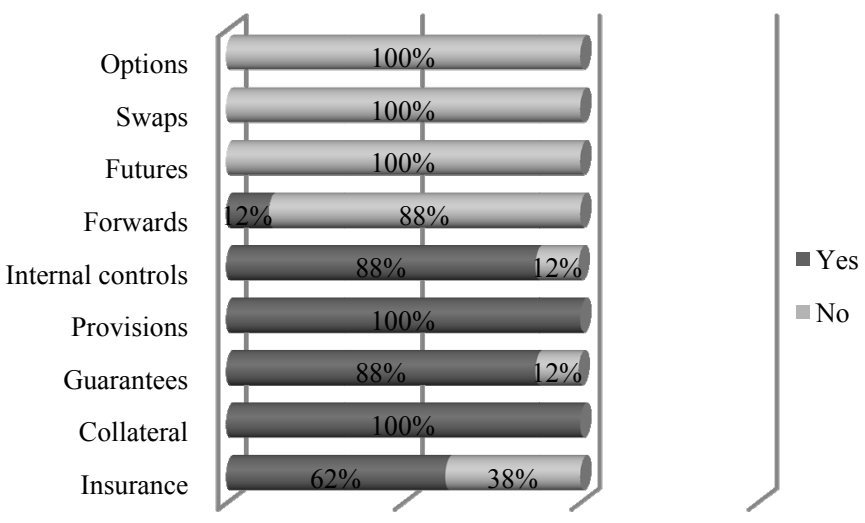

Figure 9. Hedging instruments used by BiH banks 
After all the measures for protection against risk are taken, banks need to see how shall (or how did) the risks they managed in the previous period influence the entire business operations of the bank. This is done on the basis of certain profitability indicators that need to show how the bank performed business operations in the past period and use it to plan business operations for the future. Figure 10 shows that $\mathrm{BiH}$ mainly use indicators of interest earning assets and net interest margin indicators, which cover $21 \%$ of all the indicators used. They are followed by liquidity indicators (19\%), profitability indicators (18\%), and indicators of financial structure (16\%). Other indicators stated by the respondents, namely cash flow 1 and 2 and debtor income assessment, take 5\% of the total percentage of used indicators.

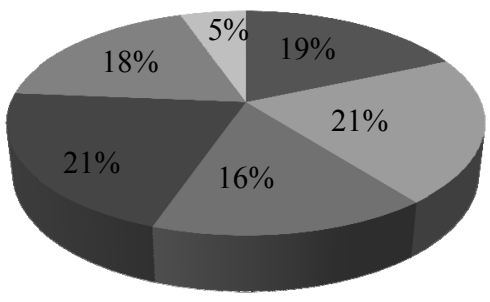

$$
\begin{aligned}
& \text { Liquidity indicators } \\
& \text { Indicators of interest earning assets } \\
& \text { Indicators of financial structure } \\
& \text { Net interest margin indicators } \\
& \square \text { Profitability indicators } \\
& \text { Some other indicators }
\end{aligned}
$$

Figure 10. Financial performance indicators used by BiH banks

If the usage of indicators is compared for the conventional and Islamic banks (Figure 11), it can be noticed that these two types of banks equally use indicators of interest earning assets and net interest margin indicators, while the Islamic banks uses liquidity indicators, indicators of financial structure, and profitability indicators more. On the other hand, while the Islamic bank does not use cash flow 1 and 2 and debtor income assessment, as well as the other indicators, $28.57 \%$ of the conventional banks use these indicators.

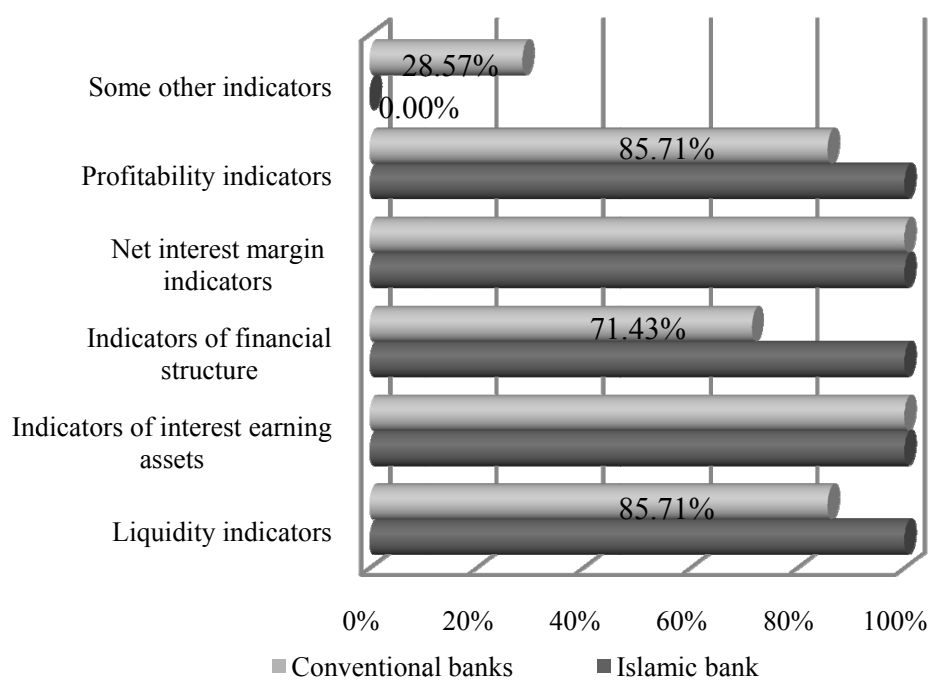

Figure 11. Differences in financial performance indicators usage by conventional and Islamic banks

The global financial crisis made the survival of many banks questionable. Therefore, this research, above other things, tried to investigate whether, and to what extent, $\mathrm{BiH}$ banks are competent to manage risks under such circumstances. As it can be noticed from Figure 12, not one respondent stated that their bank is incompetent to manage any type of risk, which is very positive and praiseworthy of $\mathrm{BiH}$ banks. As to certain types of risks, the banks are most prepared to manage credit risk $(87.5 \%$ of the respondents stated that they are well competent to manage this type of risk, while $12.5 \%$ of the respondents stated that they are moderately competent). Seventy-five percent of the respondents stated that they are well prepared for managing liquidity risk, while $25 \%$ believe to be moderately prepared. This fact is very important under the conditions of the recent crisis, which was mainly caused by inappropriate management of credit risk and liquidity risk. The results of the survey are identical for the market and operational risks. Fifty percent of the respondents believed their banks are well prepared for managing these risks, while 50\% thought that their banks are moderately prepared. The survey 
shows that the Islamic bank is well prepared to manage all types of risk, while most conventional banks are well prepared for the credit and liquidity risks, and moderately prepared for the market and operational risks.

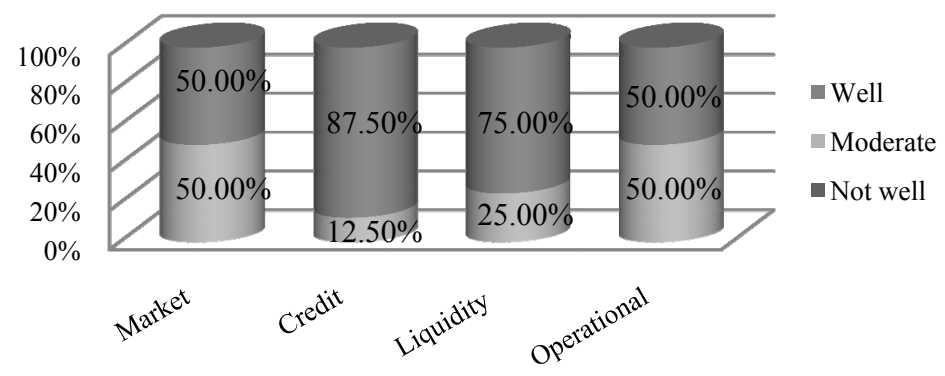

Types of risk

Figure 12. Current banks' capacity to manage identified risks

The respondents stated possible causes for the increase in risk levels in banks to be: recession, higher prices of financing sources, possible crash of euro, economy illiquidity, lower accessibility of capital, deposit withdrawal, stringent demands by the banking agencies in $\mathrm{F} \mathrm{BiH}$ and RS, qualified staff drain, etc. Due to the fact that banks' assets include certain items with different risk levels, the respondents were asked to rank the risk levels by certain items and their balance sheets. As it is illustrated on Figure 13, in conventional banks the most risky parts of assets are loans for students and pensioners, followed by loans without guarantors, Master card revolving loans, long-term loans for fixed assets, and mortgage loans. The least risky parts of the assets of the conventional banks are short-term guarantees, long-term loans for working capital, home loans, and long-term guarantees.

\section{Conventional banks' assets items according to the degree of risk}

\section{1- riskiest part of the assets}

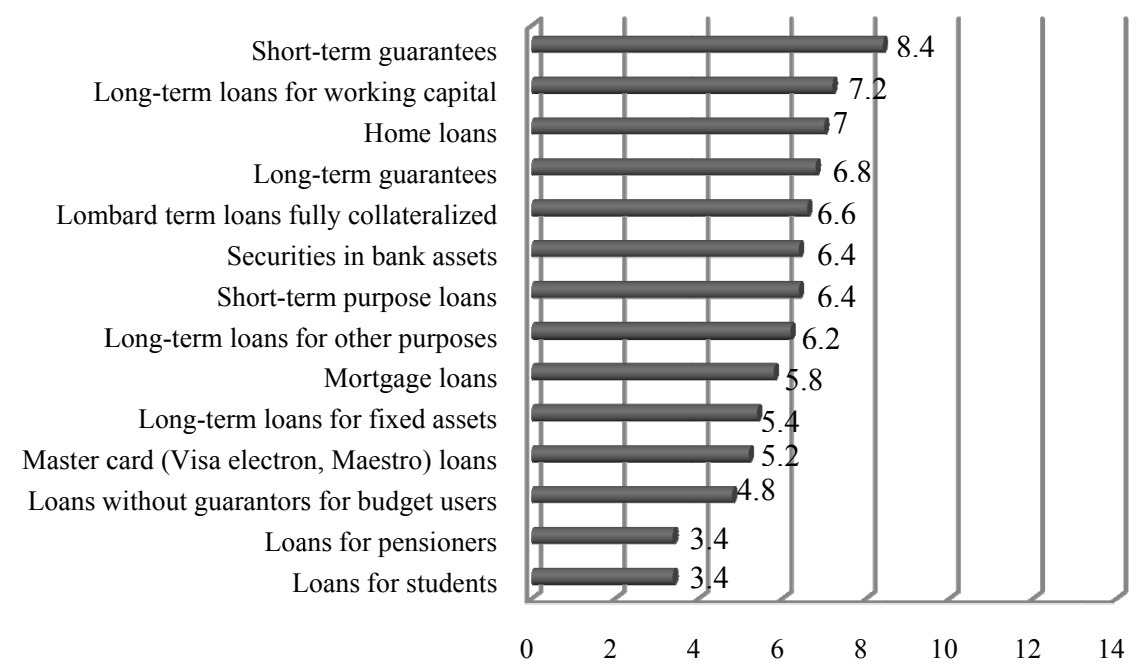

Figure 13. Conventional banks' assets items according to the degree of risk

The most risky parts of the assets of the Islamic bank are mortgage loans, short-term non purpose loans, securities, and long-term guarantees. The least risky parts of the assets of the Islamic bank are home loans and long-term all purpose loans. It is presented on Figure 14. 


\section{Islamic bank's assets items according to the degree of risk 1- $r$ iskiest part of the assets}

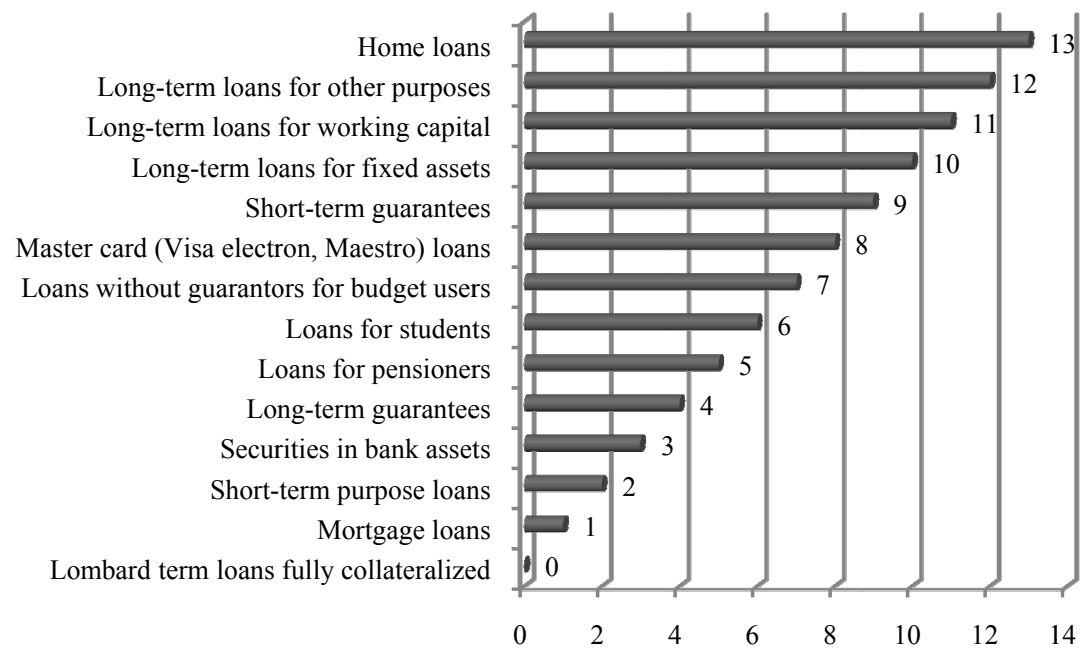

Figure 14. The Islamic bank's assets items according to the degree of risk

On the basis of the survey, we have come to the data that only $25 \%$ of the respondents believe that legal (decree-level) regulations of risk management in $\mathrm{F} \mathrm{BiH/RS}$ are well adapted to the real conditions of banks' business operations. Fifty percent of the respondents claim that the regulations are moderately adapted, while $25 \%$ think that they are poorly adapted to the real conditions under which banks operate. According to the respondents, the regulations that need to be better adapted to banks' business operations are related to:

- requests for maturity coordination for the liquidity risk, which causes banks to create costs due to short-term loans;

- standardization and professional supervision of the monitoring of the operational risk and information security;

- updating of standards, if the organized (regional) market of derivatives developed;

- addition and specification of certain sections regarding the credit risk management, etc.

\section{Conclusion and Recommendation}

The findings of the study suggested that all the banks are aware of the necessity for active risk management, but they still do not have sufficiently developed methods to manage all the risks. Regarding the difference between the conventional banks and the Islamic bank in $\mathrm{BiH}$, the Islamic bank is exposed to risk more than the conventional banks, due to both, special products which this bank offers to its clients and the lack of harmonization of the existing legal regulations and the demands of the Islamic banking. Some hedging instruments are also less available and mainly limited for the Islamic bank. Nevertheless, a special way of conducting business as well as active risk management enabled the Islamic bank to constantly make positive financial results and be competitive for the conventional banks.

It should be mentioned that all the banks that have practiced active risk management recently, especially since the outbreak of the global financial crisis in 2008, had better financial performance when compared to the period during which they did not manage risks at all, or they just did it to some extent. However, specific features of $\mathrm{BiH}$ financial market and the legal and decree-level regulations themselves do not let the banks fully manage risks.

What $\mathrm{BiH}$ needs to do in this domain is primarily to find the ways in which business operations of the Islamic bank would be compliant to the law, which currently allows for the implementation of the Islamic banking to a small degree, although it is flourishing globally. If one wants to improve this banking segment as well as the very process of managing bank risks in $\mathrm{BiH}$, the following things need to be done:

- eliminate significant limitations to the implementation and development of Islamic banking, such as prejudices, misunderstanding, intolerance, etc.; (Note 1) 
- develop the financial market further (especially for Islamic banks);

- intensify the implementation of Basel II principle (which is still at the initial stage);

- increase innovativeness and creativity in banks;

- boost transparency of banks towards stakeholders, etc.

As risk management practice is still developing and evolving on the global level, it would be interesting to conduct further research into each specific risk and examine in more detail the risk management practices of both, commercial and Islamic banks in $\mathrm{BiH}$.

\section{References}

Abdullah, M., Shahimi, S., \& Ismail, A. G. (2011). Operational risk in Islamic bank: examination of issues. Qualitative Research in Financial Markets, 3(2), 131-151. http://dx.doi.org/10.1108/17554171111155366

Anam, S., Hasan, S. B., Huda, H. A. E., Uddin, A., \& Hossain, M. M. (2012). Liquidity Risk Management: A Comparative Study Between Conventional and Islamic Banks of Bangladesh. Research Journal of Economics, Business and ICT, 5, 1-5.

Boumediene, A. (2011). Is credit risk really higher in Islamic banks? The Journal of Credit Risk, 7(3), 97-129.

Efendic, V. (2011). Possibilities for Implementation of Interest-Free Financing in the West. The Social Market Economy and Islamic Finance (Common Value-Based Approaches) (pp. 47-53). Konrad-Adenauer-Stiftung, Germany.

Hussein, K. (2010). Bank-level stability factors and consumer confidence - A comparative study of Islamic and conventional banks' product mix. Journal of Financial Services Marketing, 15(3), 259-270. http://dx.doi.org/10.1057/fsm.2010.21

Iqbal, Z., \& Mirakhor, A. (2009). Uvod u islamske financije - teorija i praksa. Mate, Zagreb.

Khan, T. (2004). Risk management in Islamic banking - A conceptual framework, distance learning leacture (PowerPoint slides). Retrieved from http://www.sbp.org.pk/departments/ibd/Lecture5_\%20Risk_Management.ppt

Khan, T., \& Ahmed, H. (2001). Risk Management: An Analysis of Issues in Islamic Financial Industry. Occasional paper No. 5, Islamic Development Bank, Islamic Research and Training Institute, Jeddah Saudi Arabia. Retrieved from http://www.sbp.org.pk/departments/ibd/Risk_Management.pdf

Kozarević, S. (2010). Rizik menadžment i osiguranje. CPA, Tuzla.

Nazir, M. S., Daniel, A., \& Nawaz, M. M. (2012). Risk Management Practises: A Comparison of Conventional and Islamic Banks in Pakistan. American Journal of Scientific Research, 68, 114-122. Retrieved from http://www.eurojournals.com/AJSR_68_14.pdf

Rose, P., \& Hudgins, S. (2005). Bankarski menadžment i finansijske usluge. Data status, Beograd.

Šverko, I. (2002). Rizična vrijednost (Value at Risk) kao metoda upravljanja rizicima u financijskim institucijama. Ekonomski pregled, 53(7-8), 640-657. Retrieved from http://hrcak.srce.hr/file/44517

Tafri, F. H., Rahman, R. A., \& Omar, N. (2011). Empirical evidence on the risk management tools practised in Islamic and conventional banks. Qualitative Research in Financial Markets, 3(2), 86-104. http://dx.doi.org/10.1108/17554171111155339

Vaughan, E. J., \& Vaughan, T. (1999). Fundamentals of risk and insurance. John Wiley \& Sons, New York.

Note

Note 1. For more details see (Efendic, 2011). 